Paper 2003-1462

\title{
The In-class Use of Assessment and Rubrics by Student Groups to Improve Presentation Performance in Biomedical Engineering
}

\author{
Jack Wasserman, Monica Schmidt, Richard Jendrucko \\ University of Tennessee at Knoxville
}

\begin{abstract}
After many years of teaching, the shift of perspective to student learning has provided the most satisfying results. The student performance has exceeded all expectations based on past courses. In addition, it is now much easier to evaluate student progress in areas that do not require a specific numerical answer. The student response has been very positive as demonstrated by a 50\% improvement in attendance. The objectives of improved communication, problem solving, and team skills in addition to a background in BME applications have been successfully demonstrated with projects, papers, and presentations.
\end{abstract}

This approach has provided additional benefits for the supervision of graduate students and for research planning. Although initially challenging, the benefits to cost ratio is so high that it is planned for incorporation in all courses in the curriculum.

\section{Introduction}

This paper presents the results of having students use the instructor's grading rubrics to assess both oral and written presentation. For the last three years, grading rubrics have been available on the course website. However, the general use of this information was unknown. The use of assessment has been shown to benefit the assessor more than the assessee $^{1}$. The act of using the assessment criteria on other individuals' work, clarifies deficiencies in the assessor's work.

"Rubrics are scoring tools containing criteria and a performance scale that allows us to define and describe the more important components that comprise complex performances and products"2. The process of developing a rubric requires the determination of performance criteria and the key factors that define the characteristics for specific performance criteria. The performance criteria with their key factors can also be used for assessment with the removal of the performance scale ${ }^{1}$. The students were required to assess both presentations and paper of other groups using the performance criteria, but using the SII assessment format.

The broad nature of biomedical engineering demands that biomedical engineers consider the specific audience then are addressing and to focus on the objective of their presentations. The methods, described in this paper, clearly demonstrated a significant improvement in the both written and oral presentations. 


\section{Background}

The purposes of BME 271, Introduction to Biomedical Engineering, has included both teaming and communication skill. The course has five member teams, which will both present and formally report on information in the five course modules.

- Cell and Tissue Engineering

- Biomechanics

- Bioinstrumentation

- Medical Imaging

- Artificial Internal Organs

The purpose of each presentation will vary from competition for funding to providing information to a medical department for budget decisions. The audience for each presentation is specified to develop the student skills. The written and oral presentations affect both the team scores and the individual scores. This process results in team participation in both processes. The roles of the team

- Team Captain - Planner

- Spokesperson - Presenter

- Recorder - Documentation

- Reflector - Assessment of team function

Are rotated so that each member will perform each role. The teams then have a capstone research project at the end of the course, which is evaluated by biomedical faculty to determine the best-proposed research project for the course.

The grading of papers and presentation has always been difficult for the faculty. The introduction of grading rubrics was the result of Pacific Crest Teaching Institute at the University of Tennessee in 1999. The rubrics have been modified as experience has been gained. The rubrics provided include initial presentation rubrics, an extended presentation rubric introduced at midterm, and a report rubric. For the assessments, the performance criteria and key criteria were provided without the separation into evaluation categories. 
ES 271 Presentation Rubric

\begin{tabular}{|c|c|c|c|c|c|c|}
\hline ITEM & $\begin{array}{r}\text { Audience } \\
10 \%\end{array}$ & $\begin{array}{r}\text { Delivery } \\
30 \%\end{array}$ & $\begin{array}{c}\text { Effectiveness } \\
20 \%\end{array}$ & $\begin{array}{r}\text { Organization } \\
15 \%\end{array}$ & \begin{tabular}{|r} 
Knowledge \\
$20 \%$ \\
\end{tabular} & $\begin{array}{c}\text { Vocabulary } \\
5 \%\end{array}$ \\
\hline $\begin{array}{c}\text { Exceptional } \\
90-100 \%\end{array}$ & $\begin{array}{l}\text { Understands needs } \\
\text { of audience and } \\
\text { addresses those } \\
\text { needs first with } \\
\text { insight about } \\
\text { concerns }\end{array}$ & $\begin{array}{l}\text { 1. Strong Emphasis } \\
\text { on key ideas } \\
\text { 2. Clear and easily } \\
\text { understood } \\
\text { 3. Good eye } \\
\text { contact } \\
\text { 4. Personality came } \\
\text { through }\end{array}$ & $\begin{array}{l}\text { Message clearly } \\
\text { defined } \\
\text { The use of graphics } \\
\text { promoted } \\
\text { understanding } \\
\text { Every idea clearly } \\
\text { explained }\end{array}$ & $\begin{array}{l}\text { First slides clearly } \\
\text { set stage for } \\
\text { presentation } \\
\text { Logical flow from } \\
\text { slide to slide } \\
\text { Final summary } \\
\text { reinforce final ideas }\end{array}$ & $\begin{array}{l}\text { Current information } \\
\text { cited } \\
\text { Able to answer all } \\
\text { questions } \\
\text { Background } \\
\text { understood }\end{array}$ & $\begin{array}{l}\text { Concise } \\
\text { language } \\
\text { Typical word } \\
\text { usage }\end{array}$ \\
\hline $\begin{array}{l}\text { Good } \\
80-90 \%\end{array}$ & $\begin{array}{l}\text { Has addressed most } \\
\text { audience needs in } \\
\text { the beginning of } \\
\text { paper and kept their } \\
\text { focus }\end{array}$ & $\begin{array}{l}\text { Paper meets most } \\
\text { objectives } \\
\text { Some Originality } \\
\text { Good Detail }\end{array}$ & $\begin{array}{l}\text { Easily readable } \\
\text { Logic } \\
\text { demonstration }\end{array}$ & $\begin{array}{l}\text { Good overall } \\
\text { organization }\end{array}$ & \begin{tabular}{|l} 
Some current \\
Information \\
Basic \\
Understanding
\end{tabular} & Mostly correct \\
\hline $\begin{array}{l}\text { Average } \\
70-80 \%\end{array}$ & $\begin{array}{l}\text { Has thought about } \\
\text { audience and paper } \\
\text { contains } \\
\text { information } \\
\text { addressing most of } \\
\text { them }\end{array}$ & $\begin{array}{l}\text { 1. } \begin{array}{l}\text { Presented } \\
\text { information }\end{array} \\
\text { 2. Could be } \\
\text { understood } \\
\text { 3. Some eye } \\
\text { contact \& animation }\end{array}$ & 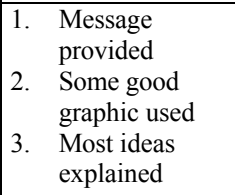 & 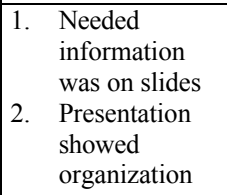 & $\begin{array}{l}\text { Information cited } \\
\text { Understanding } \\
\text { demonstrated } \\
\text { Has some } \\
\text { background }\end{array}$ & $\begin{array}{l}\text { Some correct } \\
\text { terminology } \\
\text { used }\end{array}$ \\
\hline $\begin{array}{l}\text { Fair } \\
\quad 60-70 \%\end{array}$ & $\begin{array}{l}\text { Some audience } \\
\text { needs addressed } \\
\text { somewhere in the } \\
\text { paper }\end{array}$ & $\begin{array}{l}\text { Some Objectives } \\
\text { met } \\
\text { No new ideas } \\
\text { Some planning }\end{array}$ & $\begin{array}{l}\text { Message poorly } \\
\text { defined } \\
\text { Few Graphics } \\
\text { Few ideas explained }\end{array}$ & $\begin{array}{l}\text { Some information } \\
\text { on slides } \\
\text { Little organization }\end{array}$ & $\begin{array}{l}\text { Some old } \\
\text { information } \\
\text { Limited } \\
\text { Understanding }\end{array}$ & $\begin{array}{l}\text { Few Concise } \\
\text { words used }\end{array}$ \\
\hline $\begin{array}{l}\text { Poor } \\
0-60 \%\end{array}$ & $\begin{array}{l}\text { Has spent no effort } \\
\text { considering the } \\
\text { specific audience }\end{array}$ & $\begin{array}{l}\text { 1. Wandered on } \\
\text { topic } \\
\text { 2. Hard to } \\
\text { understand } \\
\text { 3. Read information }\end{array}$ & $\begin{array}{l}\text { No graphics or } \\
\text { words not readable } \\
\text { Message not } \\
\text { defined } \\
\text { No logical } \\
\text { explanation of ideas }\end{array}$ & No organization & $\begin{array}{l}\text { No information } \\
\text { cited } \\
\text { Poor understanding } \\
\text { of material } \\
\text { Has not studied } \\
\text { background }\end{array}$ & $\begin{array}{l}\text { Street language } \\
\text { used } \\
\text { Terms are } \\
\text { incorrect }\end{array}$ \\
\hline
\end{tabular}




\section{Presentation Rubric II}

\section{EFFECTIVENESS - 20 pts}

1. Superior
a. Reviewed needs of audience and provided an initial slide to indicate how their questions will be answered.
b. Considered background of audience and provided them with the background information they would need to understand objective
c. Provided continual reference to major points of audience interest to build case for objective
d. Provided summary slide to focus final attention
e. Utilized effective visuals to provide information and maintain interest
f. Utilized analogies and/or examples that were specific to audience

\section{Adequate}
a. Audience needs were addressed during the presentation
b. Utilized visuals in a generally effective manner
c. Provided some information from more than one perspective

\section{Minimal}

a. Most needed information was provided.

b. Provided some justification to arguments based on presented information

c. Critical visuals were provided

\section{Inadequate}

a. The information was not used to reach a conclusion

b. The information was significantly incomplete

c. No relevant visuals were provided / visuals provided were a distraction 


\section{CONTENT / AUDIENCE 10 pts}

1. Superior

a. Speaker provided a variety of types of content appropriate for the task, such as generalizations, details, examples, evidence

b. Speaker adapted content in a specific way to the listener and situation. Considered specific knowledge and experience of the listener, adds explanations as necessary and refers to listener's experiences

c. Arguments added to the values and motivations of the specific listener

\section{Adequate}

a. Speaker provides enough content to meet the requirements of the task

b. Focus primarily on relevant content - sticks to topic

c. Speaker adapts the content in a general way to the listener and the situation

d. Uses words and concepts which are appropriate for the knowledge

e. Arguments adapted to a general audience

\section{Minimal}

a. Does not provide enough content to meet the requirements of the task

b. Includes some irrelevant content

c. Wanders off the topic

\section{Inadequate}

a. Says practically nothing

b. Focuses primarily on irrelevant content

c. Speaker is highly egocentric. Speaker appears to ignore the listener and the situation 
DELIVERY - 30 pts

1. Superior

a. Speaker uses delivery to emphasize and enhance the meaning of the message

b. Speaker delivers the message in a lively and enthusiastic fashion

c. Maintains eye contact with entire audience

d. Volume varies to add emphasis and interest

e. Rate varies and pauses are used to add emphasis and interest

f. Pronunciation and enunciation are very clear.

g. Speaker exhibits very few disfluencies such as "ahs", "umhs", or "you knows".

\section{Adequate}

a. Volume is not too low or too loud

b. Rate is not too fast or too slow

c. Pauses are not too long or at inappropriate spots

d. Has some eye contact

e. Pronunciation and enunciation are clear

f. Speaker exhibits few disfluencies such as "ahs", "umhs", or "you knows".

g. You are not distracted by problems in the delivery of the message

h. You do not have difficulty understanding the words of the message

\section{Minimal}

a. Volume is too low or too loud

b. Rate is too fast or too slow

c. Pauses are too long or at inappropriate spots

d. Pronunciation and enunciation is unclear

e. Speaker exhibits many disfluencies such as "ahs", "umhs", or "you knows".

f. You are distracted by problems in the delivery of the message

g. You have difficulty understanding the words of the message. You have to work to understand the words

\section{Inadequate}

a. Volume is so low that you cannot understand most of the message

b. Rate is so fast that you cannot understand most of the message

c. Pronunciation and enunciation are so unclear that most of the message cannot be understood 


\section{ORGANIZATION - 15 pts}

1. Superior

a. Message is overtly organized

b. Speaker helps you understand the sequence and relationships of ideas by using organizational aids

i. Announcing topic

ii. Previewing organization

iii. Using transitions

iv. Summarizing

\section{Adequate}
a. Message is organized
b. You do not have difficulties understanding the sequence and relationships among ideas in the message
c. You do not have to make assumptions about the sequence and relationship of ideas
d. You can put the ideas in the message into an outline

\section{Minimal}

a. Organization of the message is mixed up; it jumps back and forth

b. Organization of the message appears random or rambling.

c. Is usually reading either slides of notes.

d. You have difficulty understanding the sequence and relationships among the ideas in the message

e. You have to make assumptions about the sequence and relationship of ideas

f. You cannot put the ideas in the message into an outline

\section{Inadequate}

a. The message is so disorganized that most of the message cannot be understood 


\section{KNOWLEDGE - 20 pts}

\section{Superior}
a. Always provides documentation of key points
b. Rewords questions to insure how to provide answer
c. Able to provide answers to most questions with follow-up to insure understanding
d. Provides current information with contact references

\section{Adequate}

a. Provides current information, but does not always document source

b. General provides an adequate answer to questions

\section{Minimal}

a. Provided some relevant information

b. Was able to answer some basic questions

\section{Inadequate}

a. Most information was conjectures

b. Could not answer questions

\section{Language -5 pts}

\section{Superior}

a. Speaker makes very few grammatical mistakes

b. Speaker uses terminology and structure appropriate to topic and audience

c. Speaker used an effective variety of language techniques such as vivid language, emotional language, humor, imagery, metaphors, and simile

\section{Adequate}

a. Speaker makes few grammatical mistakes

b. Speaker uses some of the topic specific terminology

c. Speaker may provide some variety in language techniques

\section{Minimal}

a. Speaker makes many grammatical errors

b. Speaker uses very simplistic, bland language

c. Communication has a very simple grammatical structure with concrete vocabulary

d. Speaker uses occasional topic specific terminology

\section{Inadequate}

a. The grammar and vocabulary are so poor that most of the message cannot be understood 


\section{ES 271 Writing Rubric}

\begin{tabular}{|c|c|c|c|c|c|c|}
\hline ITEM & $\begin{array}{l}\text { Audience } \\
10 \%\end{array}$ & $\begin{array}{l}\text { Purpose } \\
30 \%\end{array}$ & $\begin{array}{c}\text { Clarity } \\
20 \%\end{array}$ & $\begin{array}{c}\text { Organization } \\
15 \%\end{array}$ & $\begin{array}{c}\text { Knowledge } \\
20 \%\end{array}$ & $\begin{array}{r}\text { Vocab } \\
5 \%\end{array}$ \\
\hline $\begin{array}{c}\text { Exceptional } \\
90-100 \%\end{array}$ & $\begin{array}{l}\text { Understands needs } \\
\text { of audience and } \\
\text { addresses those } \\
\text { needs first with } \\
\text { insight about } \\
\text { concerns }\end{array}$ & $\begin{array}{l}\text { Paper completely } \\
\text { meets the assigned } \\
\text { objective } \\
\text { New Concepts } \\
\text { Excellent detail }\end{array}$ & $\begin{array}{l}\text { Every idea clearly } \\
\text { explained } \\
\text { Logic easy to } \\
\text { understand } \\
\text { Audience } \\
\text { Considered }\end{array}$ & $\begin{array}{l}\text { Sections well } \\
\text { thought out } \\
\text { Paragraphs } \\
\text { organized } \\
\text { Grammar } \\
\text { perfect }\end{array}$ & $\begin{array}{l}\text { Current } \\
\text { information } \\
\text { cited } \\
\text { Understanding } \\
\text { of material clear } \\
\text { Background } \\
\text { understood }\end{array}$ & $\begin{array}{l}\text { Concise } \\
\text { language } \\
\text { Typical } \\
\text { word } \\
\text { usage }\end{array}$ \\
\hline $\begin{array}{l}\text { Good } \\
80-90 \%\end{array}$ & $\begin{array}{l}\text { Has addresses most } \\
\text { audience needs in } \\
\text { the beginning of } \\
\text { paper and kept } \\
\text { their focus }\end{array}$ & $\begin{array}{l}\text { Paper meets most } \\
\text { objectives } \\
\text { Some Originality } \\
\text { Good Detail }\end{array}$ & $\begin{array}{l}\text { Easily readable } \\
\text { Logic } \\
\text { demonstration }\end{array}$ & $\begin{array}{l}\text { Good overall } \\
\text { organization } \\
\text { Grammar } 90 \%\end{array}$ & $\begin{array}{l}\text { Some current } \\
\text { Information } \\
\text { Basic } \\
\text { Understanding }\end{array}$ & $\begin{array}{l}\text { Mostly } \\
\text { correct }\end{array}$ \\
\hline $\begin{array}{l}\text { Average } \\
70-80 \%\end{array}$ & $\begin{array}{l}\text { Has thought about } \\
\text { audience and paper } \\
\text { contains } \\
\text { information } \\
\text { addressing most of } \\
\text { them }\end{array}$ & $\begin{array}{l}\text { Paper meets major } \\
\text { objectives } \\
\text { Extension concepts } \\
\text { Adequate detail }\end{array}$ & readable & $\begin{array}{l}\text { Paper divided } \\
\text { into section } \\
\text { Grammar } 80 \%\end{array}$ & $\begin{array}{l}\text { Information } \\
\text { cited } \\
\text { Understanding } \\
\text { demonstrated } \\
\text { Has some } \\
\text { background }\end{array}$ & $\begin{array}{l}\text { Some } \\
\text { correct } \\
\text { terminolo } \\
\text { gy used }\end{array}$ \\
\hline $\begin{array}{c}\text { Fair } \\
60-70 \%\end{array}$ & $\begin{array}{l}\text { Some audience } \\
\text { needs addressed } \\
\text { somewhere in the } \\
\text { paper }\end{array}$ & $\begin{array}{l}\text { Some Objectives } \\
\text { met } \\
\text { No new ideas } \\
\text { Some planning }\end{array}$ & $\begin{array}{l}\text { Difficult to read } \\
\text { Hard to see logic }\end{array}$ & $\begin{array}{l}\text { No sections but } \\
\text { organized flow } \\
\text { Grammar } 70 \%\end{array}$ & $\begin{array}{l}\text { Some old } \\
\text { information } \\
\text { Limited } \\
\text { Understanding }\end{array}$ & $\begin{array}{l}\text { Few } \\
\text { Concise } \\
\text { words } \\
\text { used }\end{array}$ \\
\hline $\begin{array}{l}\text { Poor } \\
0-60 \%\end{array}$ & $\begin{array}{l}\text { Has spent no effort } \\
\text { considering the } \\
\text { specific audience }\end{array}$ & $\begin{array}{l}\text { Paper does not } \\
\text { address the assigned } \\
\text { objectives } \\
\text { No ideas } \\
\text { No concepts } \\
\text { No detail }\end{array}$ & $\begin{array}{l}\text { Unreadable } \\
\text { No logic }\end{array}$ & $\begin{array}{l}\text { No organization } \\
\text { Grammar }<60 \%\end{array}$ & $\begin{array}{l}\text { No information } \\
\text { cited } \\
\text { Poor } \\
\text { understanding } \\
\text { of material } \\
\text { Has not studied } \\
\text { background }\end{array}$ & $\begin{array}{l}\text { Street } \\
\text { language } \\
\text { used } \\
\text { Terms } \\
\text { are } \\
\text { incorrect }\end{array}$ \\
\hline
\end{tabular}


The assessment done by the students used the SII method ${ }^{1}$. This method consists of:

- Strengths

○ Why a strengths?

- When was it observed

- Improvements

○ Plan for Improvements

- Insights

$\circ$ A global perspective gained from the assessment

The SII method was used for affect management. The initial part provides both information and a positive feeling.

\section{PLAN}

During the first presentations in the course, the students were given sheets to assess the presentations. After the initial presentations, the scores were then compared to the initial presentations. Although the presenters wee changing for each module, the structure of the presentations could be compared.

After the initial effects were observed, a new presentation rubric was constructed based on using the previous rubric and using additional information from Scoring Rubrics in the Classroom ${ }^{2}$. The added detail was then provided to the students to provide greater clarity. The new rubric was used to allow the grader to just mark observations and calculate a grade. The change in grades was again measured.

After the first written proposal, the next proposal was placed on the web in a way that each team provided an assessment of another team.

Based on How People Learn ${ }^{3}$, the concept was to allow the students discover the key factors in good communication. The rubrics were to provide the students with the context of quality from the instructor. The effect of the change of context should be reflected in the changing communication skills during the term.

\section{Results}

The average grade for the first four presentation was 8 points lower that the following four presentations two days later. The presentations scores continued to advance even though the presenters were continually changing. By the last presentation, all the presentations demonstrated:

- An introductory slide to establish flow

- A summary slide directed to the audience with the purpose in mind

- Significantly improved eye contact and preparation

- Improved documentation of information 
- A clear focus on the objective of selling their ideas for funding

The paper showed a 15-point average gain over the term. The areas of advancement were:

- A clear definition of purpose

- Improved documentation of references

- Significant improvements in organization for the reader.

- Special consideration of the background of the audience

In an autonomous survey of the students, the majority felt they had significant improvement in both written and oral presentation skills.

\section{Conclusion and Recommendations}

The past experience of students has been directed toward producing both written and oral presentations about facts without consideration of an audience. Unfortunately, the majority of the presentations of biomedical engineers is directed toward selling ideas to a specific audience. By using the assessment process coupled with the rubrics, the student teams rapidly improved their performance. The process of having the students assess the work of students produced the greatest improvements in performance that has been seen in this course.

It is planned to create a more complete rubric for the reports and to use the first presentations and reports for assessment process. It is planned to use the student assessments on the first projects rather than grading the projects. The purpose of the initial work is to develop the students' skills so that the final project grades will reflect genuine mastery of course material.

Bibliography

1. Apple, Daniel \& Krumsieg, Karl, Process Education Teaching Institute Handbook, Crest Software, Inc. 875 NM Grant Avenue, Corvallis, OR 97330, (2000)

2. Arter, Judith, McTighe, Jay, Scoring Rubrics in the Classroom, Corwin Press, Inc., 2001

3. Donovan, M., Bransford, J., Cocking, R., How People Learn -Brain, Mind, Experience, and School, National Academy Press, 2000

JACK WASSERMAN

Jack Wasserman is a professor in the Department of Mechanical and Aerospace Engineering and Engineering Science where he has taught in the biomedical option. He is currently the Coordinator for the Biomedical Engineering Degree Program. He is the winner of 7 teaching awards and is a Fellow for the Center for Undergraduate Excellence and a Fellow of the Interactive Technology Center.

\section{RICHARD JENDRUCKO}

Richard Jendrucko is the Associate Department Chairman and professor in the Department of Mechanical and Aerospace Engineering and Engineering and Engineering Science. He has been the Coordinator for the Biomedical Engineering Program. He has served as the past chairman of the Tennessee Biomedical Engineering Conference and has served as an officer for the biomedical division of ASEE. 